DOI: https://doi.org/10.34069/AI/2021.43.07.9

How to Cite:

Benkova, K., Georgiev, Y., Raleva, S., Vlaeva, N., \& Taneva, T. (2021). Study of the values of the social workers in Bulgaria. Amazonia Investiga, 10(43), 96-104. https://doi.org/10.34069/AI/2021.43.07.9

\title{
Study of the values of the social workers in Bulgaria
}

\section{Проучване на ценностите на социалните работници в България}

\author{
Received: July 2, $2021 \quad$ Accepted: August 10, 2021
}

Written by:

Krasimira Benkova ${ }^{29}$

https://orcid.org/0000-0003-2456-4698

ResearcherID: AAS-9884-2021

Yavor Georgiev $^{30}$

https://orcid.org/0000-0002-0650-9962

ResearcherID: G-9709-2016

Stanimira Raleva ${ }^{31}$

https://orcid.org/0000-0003-2728-0068

ResearcherID: AAT-1893-2021

Nadia Vlaeva ${ }^{32}$

https://orcid.org/0000-0001-9111-4430

ResearcherID: AAS-9874-2021

Tanya Taneva ${ }^{33}$

https://orcid.org/0000-0002-1097-7857

ResearcherID: AAT-1882-2021

\begin{abstract}
The purpose of this article is to study the priority motivation values of the social workers in Bulgaria and the factors influencing them. The study covers 205 social workers, participating voluntarily and anonymously. The Schwartz questionnaire: The Portrait Values Questionnaire (PVQ) was used, adapted by Karandashev (2004). The factor influences between the most significantly manifested values of the social workers and the parameters age, sex, education, improvement of the qualification, work experience, choice of profession and need for specific knowledge and skills were verified. It has been found out that only the parameter 'choice of profession' has an influence on the value of "benevolence". The results of the study show that the priority values of the social workers coincide with the mission and purpose of the social work and confirm the results of other researchers.
\end{abstract}

\begin{abstract}
Абстракт
Целта на настоящата статия е да проучи приоритетните мотивационни ценности на социалните работници в България и факторите, които им влияят. В проучването, на доброволен и анонимен принцип, участват 205 социални работници. Изплозван е въпросникът на Schwartz: The Portrait Values Questionnaire (PVQ) по адаптация на Карандашев (2004). Проверени са факторните влияния между най-силно проявените ценности на социалните работници и показателите възраст, пол, образование, повишаване на квалификацията, стаж, избор на професия и необходимост от специфични знания и умения. Открито е влияние само на показател „избор на професия“ върху ценността „доброжелателност“. Резултатите от изследването показват, че приоритетните ценности на социалните работници съвпадат
\end{abstract}

\footnotetext{
${ }^{29}$ Professor at Faculty of Medicine, department of Medical psychology, Social work and foreign languages, Trakia University, Bulgaria.

${ }^{30}$ Assistant professor at Faculty of Medicine, department of Medical psychology, Social work and foreign languages, Trakia University, Bulgaria.

${ }^{31} \mathrm{PhD}$ student at Faculty of Medicine, department of Medical psychology, Social work and foreign languages, Trakia University, Bulgaria.

${ }^{32}$ Chief assistant professor, Faculty of Medicine, department of Medical psychology, Social work and foreign languages, Trakia University, Bulgaria.

${ }^{33}$ Associated professor at Faculty of Economic, department of Social Sciences and Business Language Training, Trakia University, Bulgaria.
} 


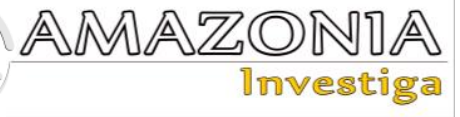

Keywords: social work, values, PVQ, personal values. с мисията и целта на социалната работа и потвърждават резултатите на други изследователи.

Ключови думи: социална работа, ценности, PVQ, личностни ценности.

In the course of its development, social work turns into a profession of strongly normative nature. At the same time it is based on a strong tradition of charity, a result of the Christian religion preaching love for the others and personal obligation for help and support for those in need.

The fundamental purposes and mission of the social work are founded on the practitioners' convictions (Reid, 1992). Within this meaning, social work is not a simple technology, it is a rather value-based and value-inspired effort aiming to help the vulnerable through complex methods of intervention (Timms, 1983).

The values of the social work should not represent a random or variable set of norms and prescription or a mirror of the public preferences and highlights; they should rather represent a standardized reflection of collective responsibility, which is implied from the role of social work in the society (Levy, 1973).

Today the spheres of activity of the social workers are so diverse that in order to answer the question "Who are we?" is not only a matter of professional solidarity or theoretical interest but an important condition for professional-value and moral and ethic self-determination. This preconditions the purpose of the present article to outline the priority motivation values of he social workers in Bulgaria and the factors influencing them.

\section{Theoretical Framework}

The values are subject of a scientific and philosophic interest on the side of philosophers and scientists (E. Durkheim, M. Weber, T. Parsons, W. Thomas, F. Znanetski). Currently the value related issues become more and more topical in the conditions of quickly changing social reality and the ascertained value crisis (Fotev, 2012; 2019).

Milton Rokeach considers values as "abstract ideas, either positive or negative, not related to a particular subject or situation, expressing a 
conviction about types of behaviour and preferred objectives" (Rokeach, 1973).

Schwartz (2012) claims that "when we think about values, we think about what is important for us in life". According to his concept, each one of us has multiple values (success, security, benevolence), each of which has a different degree of significance. A given value may be important for some but unimportant for others. The value theory of Schwartz is based on a value concept outlining six basic specifications (values as convictions, values as goals, values as standards, values are not bound by a specific activity, values have a hierarchy, values have a relative nature; see Kluckhohn, 1951; Morris, 1956; Rokeach 1973).

Studying of values and value orientations of separate social groups, professional communities, civil associations is of special interest. In this connection it is important to note that not only the conduct of empirical studies but also extensive interpretation of their results are important for rationalization of the events in the social reality.

The theoretical developments are a tool for rationalization of multiple processes and phenomena happening in the social sphere, including the issue of values. At the same time there is a problem related to difficulties using the theoretical developments for interpretation of empirical data - e.g. the use by different researchers of the concepts of 'values' and 'value orientation'. In the present article priority is given to the concept of 'values', the difference in the two concepts is considered, without being subject of special analysis.

In this particular case the problem of values carried by the social workers is outlined. For the purposes of the present article, the theory of Shalom Schwartz was used and applied with regard to values (Schwartz, 2012). Generally this theory considers values as a reflection of the motivation goals of the individuals and factors influencing emotions and conduct both in the personal and professional life.

The theory of study of individual values developed by Schwartz is based on 1) Milton Rokeach's concept for terminal and instrumental values, and 2) Shalom Schwartz's concept for the motivation goals of the value orientations and the universal nature of basic human values (Karandashev, 2004).
The theory developed by Shalom Schwartz considers basic values recognized by people with different cultures. It identifies 10 motivation types of values and standardizes the dynamic relations between them. According to this concept, some values are in conflict with others (e.g. benevolence and authority), while others are compatible (conformity and safety). The "structure" of values relates exactly to such conflicts and compliance between them (Schwartz, 2012). According to the author, the values are structured in a similar way in the different cultural groups. This gives a reason for the assumption of the author of this concept that there is a universal organization of human motivation. Although the nature of values and their structure are universal, there may be significant differences between individuals and groups in their attitude towards the relative significance given to values. This means that according to Shalom Schwartz, the different individuals and groups have different value priorities or hierarchies.

Social work has clearly defined professional values, such as: equal opportunities for everybody, guaranteeing aid to everyone, responsibility to other people's lives, participation of the individual in making decisions related to his well being, confidentiality, ability for free choice (NASW, 2017).

Tartakovsky \& Walsh (2018) state that "considered within the context of the theory of values developed by Shalom Schwartz, it is evident that the official documents of social work emphasize on the values of self-transcendence and openness to change". More specifically, in the opinion of Tartakovsky \& Walsh, the social workers must consider the values benevolence, universalism and self-direction as significant. These values are oriented towards change and have a strong social focus and within this meaning they aim at stimulating personal growth and development, as well as justice and equality in the society (Tartakovsky \& Walsh, 2018, p.117).

However, very few empirical works study the values of the social workers and "whether they correspond to the officially announced ethos and values of the profession" (Tartakovsky \& Walsh, 2018, p.115).

The values of the social workers were studied with Schwartz's instrument: The Portrait Values Questionnaire (PVQ) from Knafo \& Sagiv, (2004), Tartakovsky, E. (2016), Tartakovsky, E., 


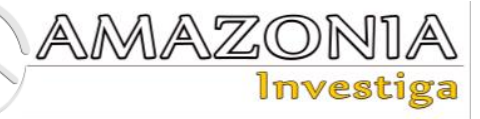

\& Walsh, S. D. (2018). The first study (Knafo \& Sagiv, 2004) was carried out in Israel, the obtained results for the social workers were compared with those of representatives of 31 other professions. The second study (Tartakovsky, 2016) considers the dependencies between the values of the social workers and the occupational burnout syndrome. The third one (Tartakovsky, \& Walsh, 2018), explores whether the values of the social workers as a professional group differ from those of the society. Abbott (1999) examines the values of the social workers using a Professional Opinion Scale (POS), investigating whether the social workers from different cultures share the same values. Wilks (2004) uses Vignettes as a method of studying the values of the social workers.

\section{Methodology}

The purpose of the study is to explore the priority values for the social workers and the influence of the socio-demographic specifications and the choice of profession of the respondents on such values.

The study was carried out among social workers carrying out social services in the community, in specialized institutions and the departments of Social Assistance Directorate on the territory of two districts in Bulgaria. There were 205 social workers participating in it. The study was carried out on an anonymous and voluntary principle and each questionnaire was accompanied by an informed consent card. Schwartz's questionnaire The Portrait Values Questionnaire (PVQ) was used, as adapted by V.N. Karandashev (2004).

The methodology contained 40 descriptions of people meeting any of the 10 basic values. The respondent had to judge the extent to which the description relates to him or not. This is performed by means of a 5-point scale: $4=$ Very relevant to me, $3=$ Relevant to me, $2=$ Somehow relevant to me, $1=$ Fairly relevant to me, $0=$ Not relevant to me, and $-1=$ Absolutely not relevant to me. The ten basic values are: Benevolence, Universalism, Self-direction, Security, Conformity, Hedonism, Tradition, Stimulation, Achievements, Power.

The processing of the obtained data was carried out by means of Microsoft Excel and the statistical package Statistica 12. The data were entered and processed by Statistica 12. the following basic statistical analyses were used: descriptive statistics, dispersion analysis (ANOVA), with level of significance for zero hypothesis $p>0.05$, Student-Fischer's T-test.

\section{Limitations of the research}

The study has its subjective and objective limitations, related to the refusal of some of the social workers to fill out the relevant questionnaires and with the failure to obtain permissions for performance of the study in some social services.

\section{Results and Discussion}

\section{Specification of the participants in the study}

The profile of the respondents may be explained with the following figure: A woman aged between 39 and 49, working at Social Assistance Directorate, with work experience over 10 years, education other than Bachelor's or Master's degree in Social activities, with additional training by means of courses, considering that the profession requires specialized knowledge and skills, who has decided to become a social worker at her personal choice (Table 1). 
Table 1.

Summarized specification of the participants in the study.

\begin{tabular}{|c|c|c|c|c|c|c|c|}
\hline \multicolumn{8}{|c|}{ Socio-demographic specification } \\
\hline Workplace & Age & Sex & $\begin{array}{l}\text { Work } \\
\text { experience }\end{array}$ & Education & $\begin{array}{l}\text { Additional } \\
\text { qualification }\end{array}$ & $\begin{array}{l}\text { Choice of } \\
\text { profession }\end{array}$ & $\begin{array}{l}\text { Need for } \\
\text { specific } \\
\text { knowledge } \\
\text { and skills }\end{array}$ \\
\hline \multirow{2}{*}{$\begin{array}{l}\text { Social } \\
\text { Assistance } \\
\text { Directorate } \\
168 \text { people }\end{array}$} & $\begin{array}{l}22-38 \text { yrs } \\
\text { old } \\
71 \text { people }\end{array}$ & Women & 78 people & $\begin{array}{l}\text { Bachelor's } \\
\text { degree in } \\
\text { Social } \\
\text { activities } \\
56 \text { people }\end{array}$ & $\begin{array}{l}\text { Courses, } \\
\text { workshops } \\
105 \text { people }\end{array}$ & $\begin{array}{l}\text { Personal choice } \\
121 \text { people }\end{array}$ & Yes \\
\hline & $\begin{array}{l}39-49 \text { yrs } \\
\text { old }\end{array}$ & $\begin{array}{l}183 \\
\text { people }\end{array}$ & 6 to $10 \mathrm{yrs}$ & $\begin{array}{l}\text { Master's } \\
\text { degree in }\end{array}$ & Specialization & $\begin{array}{l}\text { Due to the lack } \\
\text { of another }\end{array}$ & 191 people \\
\hline Social service & 83 people & & 47 people & $\begin{array}{l}\text { activities } \\
43 \text { people }\end{array}$ & 7 people & $\begin{array}{l}\text { opportunity } \\
19 \text { people }\end{array}$ & \\
\hline \multirow[t]{2}{*}{37 people } & $\begin{array}{l}50-60 \text { yrs } \\
\text { old }\end{array}$ & Men & Over 10 yrs & $\begin{array}{l}\text { Other } \\
\text { education }\end{array}$ & $\begin{array}{l}\text { University } \\
\text { education }\end{array}$ & $\begin{array}{l}\text { By notion of } \\
\text { chance }\end{array}$ & No \\
\hline & 45 people & 21 people & 80 people & 104 people & 22 people & 65 people & 12 people \\
\hline
\end{tabular}

\section{Values of the participants in the study}

The priority values for the social workers are: benevolence (rank 1), universalism (rank 2) and self-direction (rank 3).
According to the methodology used (Karandashev, 2004), the results (the mean values and scores) are successively represented in Table 2.

Table 2.

Mean values of Individual's profile and their corresponding rank.

\begin{tabular}{lll}
\hline Value & mean & rank \\
\hline Benevolence & 2,87 & 1 \\
Universalism & 2,83 & 2 \\
Self-direction & 2,65 & 3 \\
Security & 2,45 & 4 \\
Conformity & 2,32 & 5 \\
Hedonism & 2,05 & 6 \\
Tradition & 2,01 & 7 \\
Stimulation & 1,86 & 8 \\
Achievements & 1,81 & 9 \\
Power & 0,71 & 10 \\
\hline
\end{tabular}

\section{Factor influences}

We searched for factor influences between the most pronounced values of the questioned social workers and the parameters age, sex, education, improvement of the qualification, work experience, choice of profession and need for specific knowledge and skills.

$\mathrm{H}_{0}$ : The parameters will not have influence on the Individual's profile, $\mathrm{p}>0.05$.

$\mathrm{H}_{1}$ : The parameters will have influence on the Individual's profile, $\mathrm{p}<0.05$.

The influence of all parameters on the three most strongly expressed values has been studied. The results of the study show influence only under the parameter of "choice of profession" on the value of 'benevolence'. The results are represented in Table 3.

We also searched for statistically significant differences in the mean values. A T-test shows that the social workers who have started work 'by notion of chance' show a statistically significant difference in the mean values in comparison to their colleagues who have started work 'due to the lack of another opportunity for career development', in their individual profile the leading value is 'Benevolence'.

The social workers who have started work at their "personal choice" show a statistically significant difference in the mean values compared with their colleagues who have started work "due to the lack of another opportunity for 


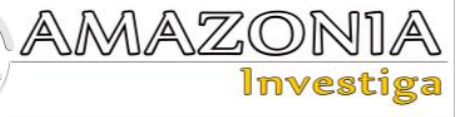

career development", in their personal profile the leading value is 'Benevolence'. The difference is big and statistically significant, with $\mathrm{p}<0.01$.
These results show that the social workers who have chosen the profession of social work "at their personal choice" and "by notion of chance" show to a larger extent 'Benevolence' towards their colleagues.

Table 3.

Influence of the parameter of 'choice' on the value 'Benevolence'

\begin{tabular}{|c|c|c|c|c|c|}
\hline $\begin{array}{l}\text { Independent } \\
\text { variable }\end{array}$ & Dependent variable & Degree & $\overline{\mathrm{x}}$ & $\mathrm{F}, \mathrm{p}$ & T-test \\
\hline \multirow{3}{*}{$\begin{array}{l}\text { Choice of } \\
\text { profession }\end{array}$} & \multirow{3}{*}{ Benevolence } & Personal choice & 2.97 & \multirow{3}{*}{$\begin{array}{l}F=5.75 \\
p<0.01\end{array}$} & \multirow{3}{*}{$\begin{array}{l}\mathrm{t}_{1,2}=3.36 \\
\mathrm{p}<0.01 \\
\mathrm{t}_{3,2}=2.02 \\
\mathrm{p}<0.05\end{array}$} \\
\hline & & $\begin{array}{l}\text { Due to the lack of } \\
\text { another opportunity } \\
\text { for career } \\
\text { development }\end{array}$ & 2.40 & & \\
\hline & & By notion of chance & 2.81 & & \\
\hline
\end{tabular}

\section{Discussion}

- Regarding the common specification of the participants in the study

\section{"Age" parameter}

With respect to the age groups in which the social workers are allocated, observations show the introduction of young professionals in practice, and the presence of social workers in the age group from 50 to 60 and over 60 . We believe that the second group of social workers can be extremely useful in their capacity of mentors of their young colleagues and a corrective in their professional behavior.

\section{"Workplace" parameter}

The larger relative share of the respondents exercise their profession in the departments of Social Assistance Directorate. A significantly lower share belongs to the workers providing various social services. The methodologies under which the social services are functioning, rarely presuppose the availability of more than one social worker. This does not mean that the social services do not need professionals in social work. The structural units at Social Assistance Directorate provide not only social benefits but also direct, accommodate and lead away the users of social services and also carry out activities related to protection of the children and adoption procedures. This presupposes the availability of a significantly higher number of social workers. Despite the process of deinstitutionalization and the state policy of decentralization, there is a tendency of centralization with respect to the social work specialists.

\section{"Sex" parameter}

The profession of social work is often described as "dominated" by women in the specialized literature of McPhail, B. A. (2004). Most frequently social work is placed in one group with the professions of nurse and teacher (Stromberg, 1988). Giovannoni and Purvine (1974) state that social work is regarded as "female" profession because "its functions are characterized as continuation of the caring role of the woman and the significance of the women in the early development of the profession". The study shows that this tendency is still preserved.

\section{"Work experience" parameter}

Regarding the work experience, the largest relative share according to the study belongs to the group of social workers from 6 to 10 and over 10 years of work experience. This speaks of the availability of specialists with long-term experience and practice, who are experts in social work and can render expert aid to their colleagues, for example through various forms of supervision. The relative share of the social workers with work experience up to 5 years confirms the introduction of young cadres in practice.

\section{The parameter of "education"}

More than half of the respondents have education different than the required for the profession. The results confirm the study of Benkova et all. (2020, p.11), according to which $47.41 \%$ of the questioned social workers do not have education in Social activities. Such social workers must undergo specialized university education as envisaged in the statutory provisions in order to practice the profession. 
In their standards, the organizations of social workers on an international, European and national level have adopted requirements for permanent improvement of the practitioners' qualification. The permanent training ensures maintenance of high quality in practice. The higher educational level and the additional training are associated with a higher status and reputation and lead to satisfaction with the performed activity (Vila, 2000).

The social workers who have passed additional courses and university studies have a wider range of scientific knowledge which substantiate their decisions and practical behavior and bring them additional confidence. This means that they have a higher level of motivation for acceptance of new tasks and pursue their goals with perseverance despite the obstacles and difficulties they face. The results show that the largest relative share of the respondents have chosen their profession as personal choice, i.e. their choice is voluntary and intentional regarding all challenges and difficulties of the profession. In our opinion this means that he choice of profession is connected with the argument to help those in need and that for them social work is the profession through which they could accomplish their desire to care for the others.

\section{The parameter of "Specific knowledge and skills"}

There is an increasing need for specific knowledge and skills demonstrated by the social workers. These results are obtained regardless of whether the participants have a Bachelor's or a Master's degree in Social activities. This speaks of realized need for 1) constant increase in the practitioners' expertise; and 2) acquisition of university education by those who do not have one.

\section{- Regarding the values of the participants in the study}

The results of the study show that the priority values of the respondents coincide with the mission and objective of the social work. The results confirm the research carried out by Knafo \& Sagiv, (2004), Tartakovsky, E. (2016), Tartakovsky, E., \& Walsh, S. D. (2018). The questioned social workers are people suppressing their own needs in order to help others. This shows that the respondents are people who are extremely concerned with the well-being and prosperity of the people in need. The social worker has the vocation to render support and help to those in need.

\section{Regarding the influence of the factor 'choice of profession' on the values}

Studies show that the problems in the respondents' own families are a factor for choosing the profession of social work (Rompf, $\&$ Royse, 1994). Such a hypothesis has not been explored in the present article. Other researchers consider the choice as a result of attitudes, objectives and values (Markus \& Kitayama, 2003) and a parameter of the internal attitudes on the basis of which people make a conclusion about their own preferences (Festinger, 1957; Sela, Berger, \& Kim, 2017). The results showed that the only factor which influences the values of the social workers is the "choice of profession". ANOVA showed that it only influences the value of "benevolence" (see Table 3).

It depends on the individual what he would become and what the world in which he lives in would be. This is the meaning of the famous thesis of Sartre: "Existence precedes essence". This means that first of all the man is and then he is this or that; the individual must create his own identity; he defines himself gradually by rushing into the world as a party, fighting on his own; and the definition remains always open; it cannot be said what the man is before his death or what the mankind is before it disappears. Stemming from this idea, Sartre develops his opinion on freedom and personal choice in "Being and Nothingness" and more specifically in the "Cafe Waiter". Benefiting from his personal freedom, the waiter takes the role as such without being such in reality. He needs to be a waiter in order to be a part of the society. Without recognition from the others he cannot exist as a waiter because he actually is not. A man makes a choice of his own, entirely assuming all possible consequences of his act, without having support from the outside or inside in him (Benkova \& Kolev, 2011).

Within this meaning, the respondents who have chosen the profession on their own have done so because they feel a necessity to be social workers and to help those in need.

\section{Conclusions}

The results of the study show that the social workers bear values corresponding to those of the profession; they do not reduce their practice to technical performance of certain requirements and criteria but want to help people. It is 


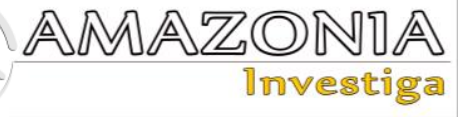

important for the participants in the study to take care of the well-being of the society members. The present article confirms the conclusions of other researchers in the field of values of social workers. This outlines future perspectives and challenges for the study of the value-related issues in the social work, intended to cover a larger number of participants and a study and comparison of the values of the social workers internationally.

\section{Bibliographic references}

Abbott, A. A. (1999). Measuring social work values: A cross-cultural challenge for global practice. International social work, 42(4), 455-470. DOI: 10.1177/002087289904200407

Benkova, K. (2013). Ethics of social work. Bogomilovo: Contrast publ. ISBN 978-954-338061-9 link: https://plus.bg.cobiss.net/opac7/bib/1265817060 Benkova, K., \& Kolev, G. (2011). Texts and comments on ethics: for students majoring in Social Activities. Bulgaria: Stara Zagora, Alfamarket+. ISBN 978-954-9443-59-2 link: https://plus.bg.cobiss.net/opac7/bib/1248510948 Benkova, K., Vlaeva, N., Peeva, K., \& Raleva, S. (2020). Defining the degree of work attractiveness in the Protected Housing service in Bulgaria. European Journal of Social Work, 1-15. DOI: 10.1080/13691457.2020.1738348

Dominelli, L. (2010). Globalization, contemporary challenges and social work practice. International Social Work, 53 (5), 599-612. DOI: 10.1177/0020872810371201

Festinger, L. (1957). A theory of cognitive dissonance. Stanford, CA: Stanford University Press

Fotev, G. (2012). Spheres of values. New Bulgarian University. Sofia, ISBN: 978-954535-701-5

Fotev, G. (2019). European values. The new constellation. New Bulgarian University. Sofia. ISBN: 9786192330651

Giovannoni, J. M., \& Purvine, M. E. (1974). The myth of the social work matriarchy. Official Proceedings 100th Annual Forum of the National Conference on Social Welfare. New York: Columbia University Press, 166-195 link: https://hdl.handle.net/10622/76BB572A-9A6746CE-A2AE-A55992D868E8

Karandashev, V.N. (2004). Schwartz's methodology for the study of personal values. SPb.: Speech. ISBN 5-9268-0299-7

Kluckhohn, C. (1951). Values and valueorientations in the theory of action: An exploration in definition and classification. In T. Parsons \& E. Shils (Eds.), Toward a general theory of action. Cambridge, MA: Harvard
University Press. ISBN 9780674863507, 388-433

Knafo, A., \& Sagiv, L. (2004). Values and work environment: Mapping 32 occupations. Eur J Psychol Educ, 19, 255-273. DOI: 10.1007/BF03173223

Levy, C. S. (1973). The value base of social work. Journal of education for social work, 9(1), 34-42

Markus, H., \& Kitayama, S. (2003) Culture, Self, and the Reality of the Social, Psychological Inquiry, 14, 3-4, 277-283, DOI: 10.1080/1047840X.2003.9682893

McPhail, B. A. (2004). Setting the record straight: social work is not a female-dominated profession. Social work, 49(2), 323-326. DOI: 10.1093/sw/49.2.323

Morris, C. W. (1956). Varieties of human value. Chicago, IL: University of Chicago Press. ISBN10: 0226538826

National Association of Social Workers (NASW) (2017). Code of ethics of the National Association of Social Workers. Retrieved from https://www.socialworkers.org/About/Ethics/Co de-of-Ethics/Code-of-EthicsEnglish

Reid, N.P. and Popple, P.R. eds (1992). The Moral Purposes of Social Work: The Character and Intention of a Profession. Nelson-Hall, First Edition. ISBN-10: 0830412468

Rokeach, M. (1973). The nature of human values. New York: Free Press. ISBN-10: 0029267501

Rompf, E. \& Royse, D. (1994). Choice of Social Work as a Career: Possible Influences, Journal of Social Work Education, 30, 2, 163-171, DOI: 10.1080/10437797.1994.10672227

Sagan, R., Sitek, S. \& Szajnowska-Wysocka, A. (2020). The impact of globalisation on regional identity: the example of Silesian identity. Bulletin of Geography. Socio-economic Series,48(48), 83-111. DOI: 10.2478/bog-20200015

Schwartz, S. H. (2012). An overview of the Schwartz theory of basic values. Online readings in Psychology and Culture, 2(1), 11.

Sela, A., Berger, J., \& Kim, J. (2017). How selfcontrol shapes the meaning of choice. Journal of Consumer Research, 44(4), 724-737, DOI: 10.1093/jcr/ucx069

Social Services Act (2019). Prom. State Gazette V. issue 24 of March 22, 2019. Retrieved from: https://www.lex.bg/bg/laws/ldoc/2137191914

Stromberg, A. H. (1988). Women in femaledominated professions. In A. H. Stromberg \& S. Harkess (Eds.), Women working, Mountain View, CA: Mayfield. 206-224 link: https://scholar.google.com/scholar?hl=bg\&as_s $\mathrm{dt}=0 \% 2 \mathrm{C} 5 \& \mathrm{q}=$ Women $+\mathrm{in}+$ female- 
dominated+professions+Stromberg+1988\&btnG $=$

Tartakovsky, E. (2016). Personal value preferences and burnout of social workers. Journal of Social Work, 16(6), 657-673. DOI: $10.1177 / 1468017315589872$

Tartakovsky, E., \& Walsh, S. D. (2018). Value Preferences of Social Workers. Social work, 63(2), 115-124. DOI: 10.1093/sw/swy007
Timms, N. (1983). Social Work Values: An Enquiry. London: Routledge and Kegan Paul.

Vila, L. (2000). The Non-Monetary Benefits of Education. European Journal of Education, 35(1), 21-32. Retrieved July 1, 2021, from http://www.jstor.org/stable/1503615

ilks, T. (2004). The Use of Vignettes in Qualitative Research into Social Work Values. Qualitative Social Work, 3(1), 78-87. DOI: $10.1177 / 1473325004041133$ 